\title{
DNA Breakage by Hydrolyzable Tannins in the Presence of Cupric Ion
}

\author{
Sanetaka Shirahata, Hiroki Murakami, ${ }^{*}$ Kazuo Nishiyama, ** \\ Itsuro Sugata, ${ }^{*}$ Kazuki Shinohara, ${ }^{*}$ Gen-ichiro NonaKa, ${ }^{* * *}$ \\ Itsuo NishioKA*** and Hirohisa OMURA* \\ Department of Food and Nutrition, Shokei Junior College, \\ Kuhonji, Kumamoto 862, Japan \\ *Department of Food Science and Technology, Faculty of Agriculture, \\ Kyushu University, Hakozaki, Fukuoka 812, Japan \\ **Department of Agricultural Chemistry, Faculty of Agriculture, \\ Miyazaki University, Funazuka, Miyazaki 880, Japan \\ ***Faculty of Pharmaceutical Sciences, Kyushu University, \\ Maidashi, Fukuoka 812, Japan \\ Received August 16, 1984
}

\begin{abstract}
DNA breakage by hydrolyzable tannins of known structures was investigated by agarose or polyacrylamide gel electrophoretic analysis. Hydrolyzable tannins could cause both double-strand and single-strand breakages in $\lambda$ DNA in the presence of $\mathrm{Cu}^{2+}$. The breaking reaction was strongly suppressed at concentrations higher than $100 \mu \mathrm{M}$ of hydrolyzable tannins. DNA breakage by various tannins was dependent upon their sorts, numbers, and binding sites of the constituent acids and polyalcohols. Metallic ions other than $\mathrm{Cu}^{2+}$ had little effect on the breaking reaction.
\end{abstract}

Tannins are widely distributed in the plant kingdom and are significant to humans because of their use as tanning agents, dyes, and drugs in addition to their wide distribution as astringent components in many foodstuffs. The chemical structures of tannins have been studied by a number of investigators for a long time, but their extremely complex and unstable structures have inhibited the progress of research. Therefore, crude tannins have been used in most studies dealing with the biological activities of tannins, which made it impossible to discuss in detail the relationship between the activity and chemical structure. However, recent developments in purification techniques and analytical methods finally made it possible to determine the chemical structures of many tannins and to test the biological activities of tannins of known structures. Especially, a few hundred kinds of tannins have been separated from various crude drugs or plants and new physiological activities have been discovered one after another. ${ }^{1)}$ The research in this field is expected to progress rapidly in the near future.

Although binding of tannins to proteins or metals is known to be their physiological activity, little information has been obtained about their action on nucleic acid. Tannins show strong reducing activity and belong to the aromatic reductones, because they have many enetriol or enediol groups per molecule. Since aromatic reductones such as pyrocatechol, catecholamines, and lignins have in common both antitumor activity and DNA or RNA breaking activity, ${ }^{2 \sim 6)}$ tannins are also expected to have such biological activities. This paper describes DNA breakage by various hydrolyzable tannins of different molecular structures.

\section{MATERIALS AND METHODS}

1. DNA and reagents. Double-stranded DNA from phage $\lambda$ was purchased from Biotech Co. Cells of $E$. coli strain RRI were cultured in essentially the same way as the method of Norgard et al. ${ }^{7)}$ Plasmid pBR322 DNA was 
prepared from this strain by the procedure of Colman et $a l^{8)}$ Metal sulfates and gallic acid were products of Nakarai Chemicals Co. All hydrolyzable tannins used were isolated from various kinds of plants and their chemical structures were determined as reported previously: of the galloyl glucoses, mono: 6-mono-galloyl glucose, ${ }^{9)}$ di: 1,6-digalloyl glucose, ${ }^{9)}$ tri: 1,2,6-trigalloyl glucose $,{ }^{10)} 3,4,5$-trigalloyl glucose,${ }^{11)}$ tetra: $1,2,3,6$-tetragalloyl glucose, ${ }^{12)}$ 1,2,4,6-tetragalloyl glucose, ${ }^{11)} 2,3,4,6$ tetragalloyl glucose, ${ }^{11)}$ penta: 1,2,3,4,6-pentagalloyl glu$\operatorname{cose}^{13)}$; hexa-, hepta-, octa-, nona-, and decagalloyl glu$\operatorname{coses}^{13)}$ were mixtures of positional isomers; of other gallotannins, 2',3,5-trigalloyl hamamelose, ${ }^{14)}$ 3,4,5-trigalloyl proto-quercitol, ${ }^{15)}$ and 3,4,5-trigalloyl quinic acid ${ }^{15}$; of ellagitannins, ellagic acid, ${ }^{16)}$ eugeniin, ${ }^{16)}$ and sanguisorbic acid dilactone ${ }^{17)}$; of other tannins, trapain. ${ }^{18)}$

2. DNA breakage test. Unless otherwise noted, the conditions of the DNA-breaking reaction were as below. A mixture of $1 \mu \mathrm{g} \lambda \mathrm{DNA}$, tannins of varying concentrations from 1 to $400 \mu \mathrm{M}$, and metallic sulfate was incubated in $30 \mu \mathrm{l}$ of $8 \mathrm{~mm}$ phosphate buffer ( $\mathrm{pH} \mathrm{7.0)}$ ) at $37^{\circ} \mathrm{C}$ for $2 \mathrm{hr}$. The reaction was stopped by adding $20 \mu \mathrm{l}$ of $15 \mathrm{~mm}$ EDTA ( $\mathrm{pH} 7$ ) containing $0.05 \%$ bromophenol blue and $15 \%$ sucrose. The sample was analysed by gel electrophoresis. As ellagic acid and sanguisorbic acid dilacton were practically insoluble in water, they were dissolved in dimethyl sulfoxide (DMSO) and the breaking reaction was carried out in $20 \%$ DMSO. The $\mathrm{pH}$ dependence was tested in $50 \mathrm{~mm}$ buffer. We used acetate buffer for $\mathrm{pH} 4$ and 5 , phosphate buffer for $\mathrm{pH} 6,7$, and 8 , Tris- $\mathrm{HCl}$ buffer for pH 9 and carbonate-bicarbonate buffer for $\mathrm{pH} 10$. Oxidation of tannins in these buffers was followed by measuring the visible spectrum using Shimadzu UV-240 spectrophotometer equipped with a constant-temperature cell holder. A reaction mixture containing $60 \mu \mathrm{M}$ tannin, $200 \mu \mathrm{M} \mathrm{Cu}{ }^{2+}$, and $8 \mathrm{~mm}$ buffer was incubated at $37^{\circ} \mathrm{C}$ in a quartz microcell and the change of the visible spectrum accompanying the oxidation of tannin was examined.

3. Gel electrophoresis. Electrophoresis was done in 0.3 or $0.7 \%$ agarose slab gel (Nakarai Chemicals Co.) using a horizontal electrophoretic apparatus $(20.5 \times 16 \times 0.3 \mathrm{~cm}$ gel) or in $8 \%$ polyacrylamide gel (Nakarai Chemicals Co.) using quartz glass tubes $(0.8 \times 8 \mathrm{~cm}$ gel $)$. The buffer for electrophoresis was $89 \mathrm{~mm}$ tris, $8.9 \mathrm{~mm}$ boric acid and $2.5 \mathrm{~mm}$ EDTA. $\mathrm{Na}_{2}$ (TBE buffer) containing $0.5 \mu \mathrm{g} / \mathrm{ml}$ ethidium bromide for agarose or $1.0 \mu \mathrm{g} / \mathrm{ml}$ for polyacrylamide gel electrophoresis. DNA fragments lager than $3 \times$ $10^{5}$ daltons were analyzed by agarose gel electrophoresis at $50 \mathrm{~V} / 10 \mathrm{~mA}$ for $15 \mathrm{hr}$ and smaller DNA fragments by polyacrylamide gel electrophoresis at $200 \mathrm{~V} / 20 \mathrm{~mA} /$ tube for $1 \mathrm{hr}$ at room temperature. For alkaline gels to detect single-strand breaks, a buffer ( $\mathrm{pH} 12.6)$ containing $67 \mathrm{~mm}$ $\mathrm{NaOH}, 33 \mathrm{~mm}$ glycine, $33 \mathrm{~mm} \mathrm{NaCl}$, and $2 \mathrm{~mm}$ EDTA was used in both the gel and running buffer. ${ }^{19)}$ Electrophoresis was done at $50 \mathrm{~V} / 10 \mathrm{~mA}$ for $15 \mathrm{hr}$ using $0.02 \%$ bromo- cresol green as a migration marker. After electrophoresis, gels were stained with $1 \mu \mathrm{g} / \mathrm{ml}$ ethidium bromide in TBE buffer for $4 \mathrm{hr}$.

4. Estimation of mean molecular weights of DNA fragments. After electrophoresis, DNA was visualized under irradiation with a short-wave ultraviolet light source. In order to quantitate DNA mass by densitometry, photographs were taken on Neopan Film using a Minolta camera with UV and red filters (Kenko Co.). Negatives were traced on a Shimadzu UV-240 spectrophotometer equipped with a gel scanner (GSC-3 type). If the exposure and development are suitable, the optical density of the developed film is known to be proportional to the amount of DNA. ${ }^{20,21)}$ The quantitativeness of this method was confirmed with known amounts of DNA. A calibration curve of molecular weights was made using $\lambda$ DNA or pBR322 DNA fragments cleaved with restriction enzymes Hind $\mathrm{III}^{22)}$ or Hae $\mathrm{III}^{23)}$, respectively. Molecular sizes of these marker DNA fragments ranged from $4.6 \times 10^{3}$ to $1.6 \times 10^{7}$ daltons. Mean molecular weights of DNA fragments yielded by treatment with tannins were computed by a microcomputer M223 mark III (Sord Computer Systems Co.) using the calibration curve and the densitometric data on the film. Since the correspondence between molecular weights of DNA fragments and distances migrated is logarithmic, DNA fragments having larger molecular weights tend to be overestimated. ${ }^{24)}$ Therefore, the relative molecular numbers of DNA fragments were calculated by dividing the optical density on the film by the molecular weight and the mean molecular weights and the mean breakage numbers were computed according to the equations below,

$$
M_{n}=\sum n_{i} M_{i} / \sum n_{i} \quad \mathrm{MBN}=M / M_{n}-1
$$

where $M_{n}$ : mean molecular weight of DNA fragments, $n_{i}$ : relative molecular number of DNA fragments having molecular weight of $M_{i}, M_{i}$ : molecular weight of DNA fragments at each measurement, MBN: mean breakage number, $M$ : molecular weight of native DNA molecules.

\section{RESULTS}

\section{Double-stranded DNA breakage by hydrolyz- able tannins}

Hydrolyzable tannins fit into three general groups according to the sorts of constituent acids, as shown in Fig. 1. The first group is gallotannins, constituted of gallic acid. The second is ellagitannins, containing hexahydroxydiphenic acid. The third group is other tannins having other acids. Double-stranded DNA breakage by these hydrolyzable tannins were examined with $\lambda$ DNA. Since $\lambda$ DNA has a homogenous molecular size of $3.2 \times 10^{7}$ dal- 
tons, it is a favorable material to detect the activity of DNA-breaking reagents.

DNA breakage by galloyl glucoses was first investigated. The number of galloyl groups in

I. Gallotannin

a. Galloyl glucose

Pentagalloyl glucose



c. Trigalloyl protoquercitol

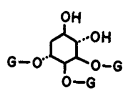

II. Ellagitannin

a. Sanguisorbic acid dilactone

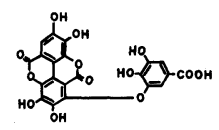

Gallic acid

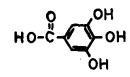

b. Trigalloyl hamamelose

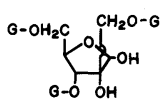

d. Trigalloyl quinic acid<smiles>O=C(O)C1C(O)OOC2OOC(=O)C21</smiles>

Ellagic acid

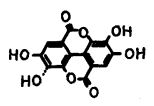

b. Eugeniin

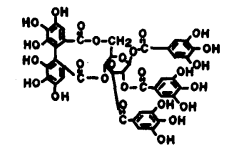

III. Others

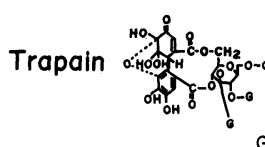

G: Galloyl $-\overbrace{\mathrm{OH}}^{\mathrm{OH}}$

FIG. 1. Structures of Hydrolyzable Tannins Examined. a galloyl glucose molecule ranged from one to ten. Figure 2 is the electrophoregram of DNAs which were treated with various concentrations of heptagalloyl glucose in the presence of $200 \mu \mathrm{M} \mathrm{Cu}{ }^{2+}$ at $37^{\circ} \mathrm{C}$ for $2 \mathrm{hr}$. As is evident from lanes 6, 7, and 8 in Fig. 2, heptagalloyl glucose caused double-strand breaks in DNA in the presence of $\mathrm{Cu}^{2+}$. Twenty-five $\mu \mathrm{m}$ heptagalloyl glucose had the strongest breaking activity. Double-stranded DNA breakage by tannins was compared by measuring the decrease of the mean molecular weight of the double-stranded DNA fragments by electrophoretic analysis. DNA breakage by galloyl glucoses is summarized in Fig. 3. Although gallic acid, a constituent of galloyl glucose, showed the strong activity depending upon its concentration, the activity of monogalloyl glucose was so weak that no breakage was detected at the concentration of $400 \mu \mathrm{m}$. When the number of galloyl groups in a molecule increased from two to ten, DNA breakage was scarcely detected at concentrations higher than $100 \mu \mathrm{M}$ of tannin. Each galloyl glucose showed a characteristic pattern of breakage which had a peak in the

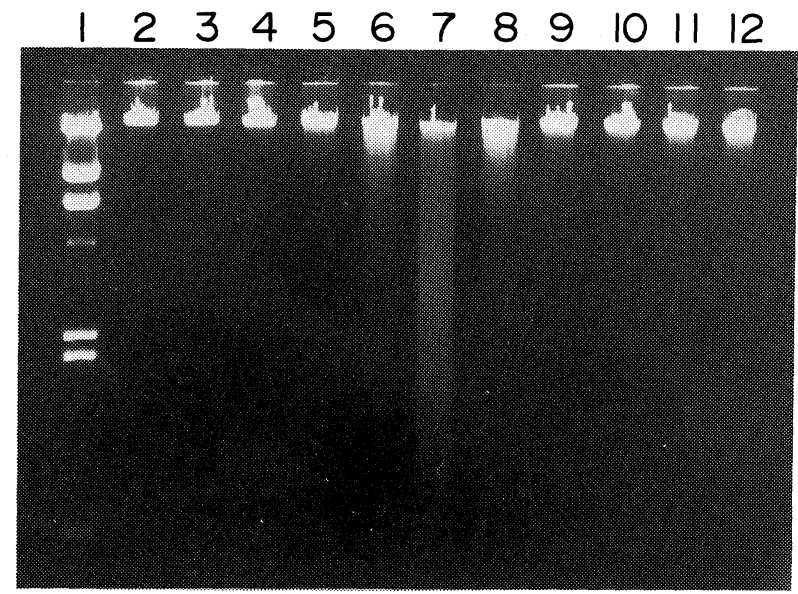

FIG. 2. Agarose Gel Electrophoregram of $\lambda$ DNA Treated with the Heptagalloyl Glucose- $\mathrm{Cu}^{2+} \mathrm{Mixture}$. $\lambda$ DNA was treated with various concentrations of heptagalloyl glucose $(1,3,6,12,25,50,75,100,200$, and $400 \mu \mathrm{M})$ in $8 \mathrm{mM}$ phosphate buffer ( $\mathrm{pH} \mathrm{7.0)}$ in the presence of $200 \mu \mathrm{M} \mathrm{Cu}{ }^{2+}$ at $37^{\circ} \mathrm{C}$ for $2 \mathrm{hr}$. After addition of $6 \mathrm{mM}$ EDTA, $0.02 \%$ bromophenol blue (BPB), and $6 \%$ sucrose, $0.7 \%$ agarose gel electrophoresis was done at $50 \mathrm{~V} / 10 \mathrm{~mA}$ for $15 \mathrm{hr}$ in a Tris-borate-EDTA (TBE) buffer containing $0.5 \mu \mathrm{g} / \mathrm{ml}$ ethidium bromide. Lane 1 , DNA-HindIII fragments. The concentration of heptagalloyl glucose: lane $2,0 \mu \mathrm{M}$; lane $3,1 \mu \mathrm{M}$; lane $4,3 \mu \mathrm{M}$; lane 5, $6 \mu \mathrm{M}$; lane 6, $12 \mu \mathrm{M}$; lane 7, $25 \mu \mathrm{M}$; lane 8, $50 \mu \mathrm{M}$; lane 9, 75 $\mu \mathrm{M}$; lane $10,100 \mu \mathrm{M}$; lane 11, $200 \mu \mathrm{M}$; lane 12 , $400 \mu \mathrm{M}$. 


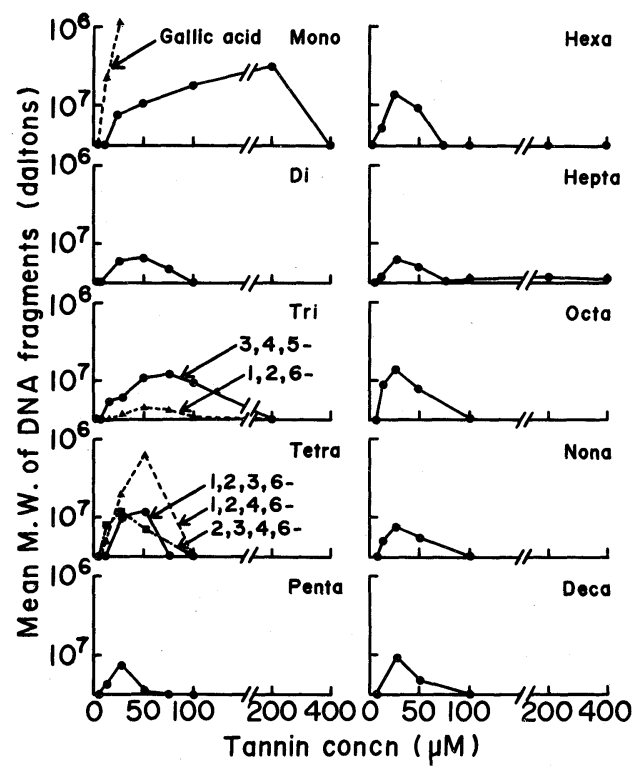

FIG. 3. The DNA-Breaking Activity of Galloyl Glucose. $\lambda$ DNAs were treated with the galloyl glucoses and $\mathrm{Cu}^{2+}$ mixture, and electrophoresed in the same conditions as in the legend to Fig. 2. The mean molecular weights of the DNA fragments produced were calculated by a microcomputer as described in MATERIALS AND Methods. The origins of the ordinate indicated the molecular weight of native $\lambda$ DNA $\left(3.2 \times 10^{7}\right.$ daltons $)$. In the tests of triand tetragalloyl glucose, the kinds of the positional isomers used are shown by the arrows. Unless otherwise noted, the experimental conditions were the same as in the following figures and table.



FIG. 4. The DNA-Breaking Activity of 2',3,5-Trigalloyl Hamamelose, 3,4,5-Trigalloyl Quinic Acid, and 3,4,5Trigalloyl Proto-quercitol.

- - 2',3,5-trigalloylhamamelose; $\mathbf{\Delta}--\mathbf{\Delta}$, 3,4,5-trigalloyl quinic acid;

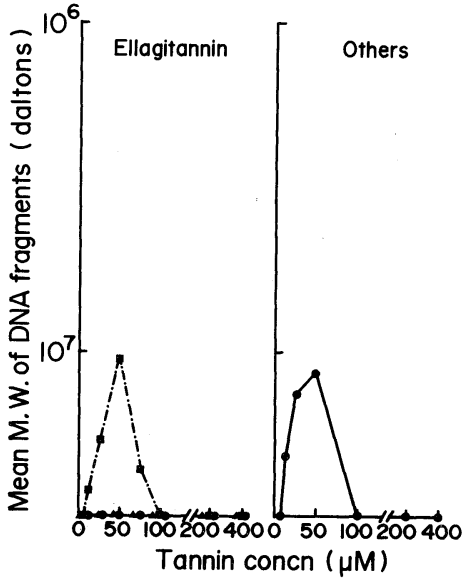

FIG. 5. The DNA-Breaking Activity of Ellagitannins and Other Hydrolyzable Tannins.

The experimental conditions were the same as in Figs. 2 and 3, except that ellagic acid and sanguisorbic acid dilactone were tested in $20 \%$ DMSO because of their insolubility in water. Ellagitannins: - ellagic acid; $\mathbf{\Delta}-\mathbf{\Delta}$, sanguisorbic acid dilactone; $\mathbf{\square}-\mathbf{-}$, eugeniin. Others: - - , trapain.

range of concentrations from 25 to $75 \mu \mathrm{M}$. Positional isomers of tri- and tetragalloyl glucose had different activity patterns.

The activity also differed according to the sort of the constituent polyalcohols, as shown in Fig. 4. 2',3,5-Trigalloyl hamamelose had the strongest activity at the concentration of $75 \mu \mathrm{M}$ and 3,4,5-trigalloyl quinic acid and 3,4,5-trigalloyl proto-quercitol at the concentration of $50 \mu \mathrm{m}$. The maximum activity decreased in the order of 2',3,5-trigalloyl hamamelose, 3,4,5trigalloyl quinic acid and 3,4,5-trigalloyl proto-quercitol.

The results of the tests with ellagitannins were shown in Fig. 5. Although no breakage was detected for ellagic acid and sanguisorbic acid dilactone, eugeniin had maximum breaking activity at the concentration of $50 \mu \mathrm{m}$. Since ellagic acid and sanguisorbic acid dilactone were practically insoluble in water, the breaking reaction was done in $20 \%$ DMSO. In order to examine the effect of DMSO on DNA breakage by hydrolyzable tannins, $\lambda$ DNAs were treated with a mixture of $25 \mu \mathrm{m}$ hexagalloyl glucose and $200 \mu \mathrm{M} \mathrm{Cu}{ }^{2+}$ in $8 \mathrm{~mm}$ phosphate buffer containing $0,1,5,10,20,30$, and 
$40 \%$ DMSO for $2 \mathrm{hr}$. The DNA breaking reaction was extremely suppressed in $1 \%$ DMSO and completely inhibited in higher concentrations of DMSO than $5 \%$. Thus, it was obscure whether ellagic acid and sanguisorbic acid dilactone had no DNAbreaking activity or their activity was inhibited by DMSO. Trapain, one of the "other tannins" group, had rather strong activity at lower concentrations and a maximum activity was found at the same concentration as for eugeniin.

As is evident from lanes 6, 7, and 8 in Fig. 2 and the decrease of the mean molecular weight of the double-stranded DNA fragments in Figs 3 , 4, and 5, hydrolyzable tannins caused double-strand breaks in the presence of $\mathrm{Cu}^{2+}$. Double-stranded DNA breakage by hydrolyzable tannins changed variously according to the sorts, numbers, and binding positions of the constituent acids and polyalcohols.
2. Course of DNA breakage by hexagalloyl glucose

We examined DNA breakage by hydrolyzable tannins in more detail in a mixture of $25 \mu \mathrm{m}$ hexagalloyl glucose (HGG) and $200 \mu \mathrm{M}$ $\mathrm{Cu}^{2+}$. Although double-strand breakage was scarcely detected in the first hour of reaction the average breakage number then gradually increased and reached 3.6 after $4 \mathrm{hr}$ (Fig. 6).

Single-strand breakage was examined by alkali gel electrophoresis. Although no singlestrand breakage was detected in the first $30 \mathrm{~min}$, obvious breaks were observed after $1 \mathrm{hr}$ in spite of the lack of double-strand breaks, so hydrolyzable tannins first broke single strands, and the accumulation of singlestrand breaks resulted in double-strand breaks. The fact that even single-strand breaks couldn't be detected at the initial stage of the reaction suggested that some activation of hydrolyzable tannins might be necessory for
A

\section{(a)}

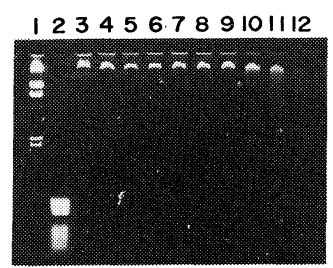

(b)

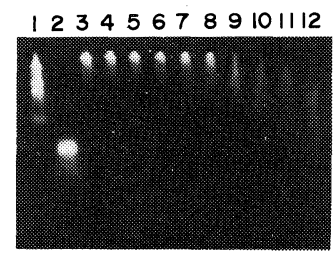

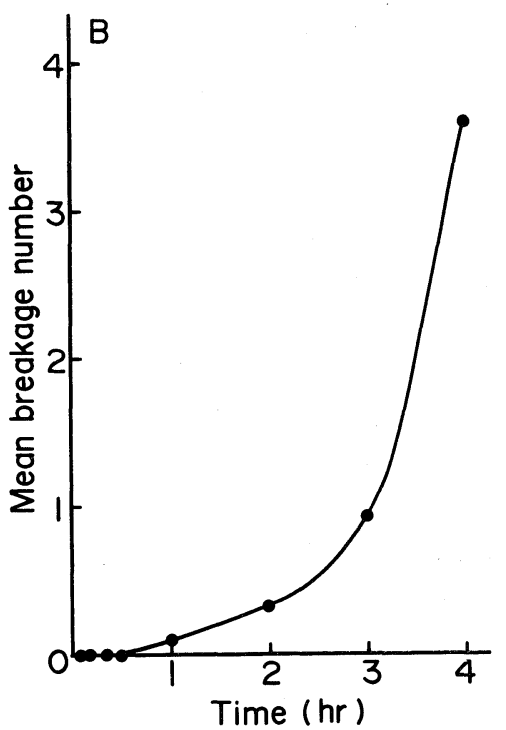

Time ( $h r)$

Fig. 6. The Course of DNA Breakage by Hexagalloyl Glucose.

DNAs $(4.2 \mu \mathrm{g})$ were incubated with a mixture of $25 \mu \mathrm{M}$ hexagalloyl glucose (HGG) and $200 \mu \mathrm{M} \mathrm{Cu}{ }^{2+}$ in $75 \mu \mathrm{l}$ of $8 \mathrm{~mm}$ phosphate buffer for various periods of time. The reaction was ended by the addition of $30 \mu \mathrm{l}$ of $30 \mathrm{~mm}$ EDTA. After addition of $0: 02 \%$ BPB and $6 \%$ sucrose to $40 \mu \mathrm{l}$ of the reaction mixture, $0.7 \%$ agarose gel electrophoresis was done using TBE buffer $(\mathrm{pH} 8.3)$ in the same conditions as in Figs. 2 and 3. The rest of the reaction mixture, after the addition of $0.02 \%$ bromocresol green and $6 \%$ sucrose, was used for alkaline gel electrophoresis using $0.7 \%$ agarose gel in the alkaline buffer $(\mathrm{pH} \mathrm{12.6)} \mathrm{in} \mathrm{order} \mathrm{to} \mathrm{detect} \mathrm{single-strand} \mathrm{breaks.}$ (A): (a) neutral gel electrophoresis ( $\mathrm{pH}$ 8.3). (b) alkaline gel electrophoresis ( $\mathrm{pH}$ 12.6). Lane 1, DNA-Hind III fragments; lane 2, pBR322 DNA-HaeIII fragments. The reaction time: lane 3, $0 \mathrm{~min}$; lane 4, $1 \mathrm{~min}$; lane 5, $5 \mathrm{~min}$; lane 6, $10 \mathrm{~min}$; lane 7, $20 \mathrm{~min}$; lane $8,30 \mathrm{~min}$; lane $9,1 \mathrm{hr}$; lane 10, $2 \mathrm{hr}$; lane 11, $3 \mathrm{hr}$; lane 12, $4 \mathrm{hr}$. (B): The course of double-stranded DNA breakage by HGG. 
the appearance of the DNA-breaking activity.

\section{Requirement of $\mathrm{Cu}^{2+}$ for DNA breakage by $H G G$}

The effect of $\mathrm{Cu}^{2+}$ on the DNA-breaking reaction by hydrolyzable tannins was investigated. DNA was treated with a mixture of various concentrations of $\mathrm{HGG}$ and $\mathrm{Cu}^{2+}$ at $37^{\circ} \mathrm{C}$ for $2 \mathrm{hr}$ and DNA breakage was examined. As shown in Fig. 7, no breakage by HGG was observed in the absence of $\mathrm{Cu}^{2+}(0 \mathrm{mM})$. However, strong activity emerged in the presence of $\mathrm{Cu}^{2+}(0.2,0.5,1.0$, and $2.0 \mathrm{~mm})$. When the $\mathrm{Cu}^{2+}$ concentration was increased from $0.2 \mathrm{~mm}$, the strong breaking activity appeared even at HGG concentrations of 75 and $100 \mu \mathrm{M}$, at which there had been no breakage observed, so possibly the suppression of breakage at higher concentrations of tannins is caused by a deficiency of $\mathrm{Cu}^{2+}$.

\section{Effects of various kinds of metallic ions and $p H$ on DNA breakage by $H G G$}

$\mathrm{Cu}^{2+}$ was absolutely required for DNA breakage by HGG. The effects of other metallic ions on the breakage were examined using HGG. The breakages caused by treatment with a mixture of various concentrations of HGG (1 to $400 \mu \mathrm{M}$ ) and $0.5 \mathrm{~mm}$ metallic ions (as sulfates) for $2 \mathrm{hr}$ were determined. The results are shown in Table $\mathrm{I}$. $\mathrm{Cu}^{2+}$ caused about 50.2 double-strand breaks per DNA molecule, but $\mathrm{Mn}^{2+}, \mathrm{Zn}^{2+}$, and $\mathrm{Fe}^{3+}$ had extremely weak activity and $\mathrm{Fe}^{2+}, \mathrm{Ni}^{2+}$, $\mathrm{Co}^{2+}$, and $\mathrm{Mg}^{2+}$ had no effect on the breaking reaction. This remarkable effect of $\mathrm{Cu}^{2+}$ might be related to the excellent catalsis by $\mathrm{Cu}^{2+}$ of the oxidation of aromatic reductones, as is evident from the fact the oxidizing enzymes of aromatic reductones are almost all copper enzymes.

The effects of $\mathrm{pH}$ on the DNA-breaking reaction were investigated. As shown in Fig. 8, the breaking activity of the HGG-Cu${ }^{2+}$ mixture was weak in acidic conditions and enhanced with increasing $\mathrm{pH}$. As the possibility that DNA was broken by $\mathrm{Cu}^{2+}$ alone at higher pH was considered, DNA was treated with



FIG. 7. Requirement for $\mathrm{Cu}^{2+}$ by the DNA-Breaking Activity of Hexagalloyl Glucose.

$\lambda$ DNAs were treated with various concentrations of $\mathrm{HGG}$ at $37^{\circ} \mathrm{C}$ for $2 \mathrm{hr}$ in the absence or presence of $\mathrm{Cu}^{2+}$ and the mean number of breaks were examined. The $\mathrm{Cu}^{2+}$ concentrations: $-\bullet, 0 \mathrm{mM} ; \boldsymbol{\Lambda}-\boldsymbol{\Delta}, 0.2 \mathrm{~mm} ; \boldsymbol{\square}--\mathbf{\square}, 0.5 \mathrm{~mm}$; *---*, $1 \mathrm{~mm} ; \bigcirc-\mathrm{O}, 2 \mathrm{~mm}$.

\section{Table I. The Effect of Metallic Ions ON THE DNA-BREAKING ACTIVITY of HeXagalloyl Glucose}

$\lambda$ DNAs were treated with various concentrations of $\operatorname{HGG}(0,1,3,6,12,25,50,75,100,200$, and $400 \mu \mathrm{M})$ in the presence of $0.5 \mathrm{~mm}$ metallic ions (as sulfates) at $37^{\circ} \mathrm{C}$ for $2 \mathrm{hr}$ and the mean breakage numbers were examined. Maximum values of the mean breakage numbers are shown in Table I.

\begin{tabular}{cc}
\hline Metallic ions & Mean breakage number \\
\hline $\mathrm{Cu}^{2+}$ & 50.2 \\
$\mathrm{Mn}^{2+}$ & $<0.1$ \\
$\mathrm{Zn}^{2+}$ & $<0.1$ \\
$\mathrm{Fe}^{3+}$ & $<0.1$ \\
$\mathrm{Fe}^{2+}$ & u.d. \\
$\mathrm{Ni}^{2+}$ & u.d. \\
$\mathrm{Co}^{2+}$ & u.d. \\
$\mathrm{Mg}^{2+}$ & u.d. \\
\hline
\end{tabular}

u.d., undetected.

$\mathrm{Cu}^{2+}$ alone at each $\mathrm{pH}$. However, no DNA breakage occurred upon treatment with $\mathrm{Cu}^{2+}$ alone in the $\mathrm{pH}$ range examined. The $\mathrm{HGG}$ solution was yellow at alkaline $\mathrm{pH}$ and the reaction was accelerated by $\mathrm{Cu}^{2+}$. The oxidation rate of $\mathrm{HGG}$ was expressed in Fig. 8 as the increase in absorbance at $420 \mathrm{~nm}$ after the incubation at $37^{\circ} \mathrm{C}$ for $20 \mathrm{~min}$. Since the oxid- 


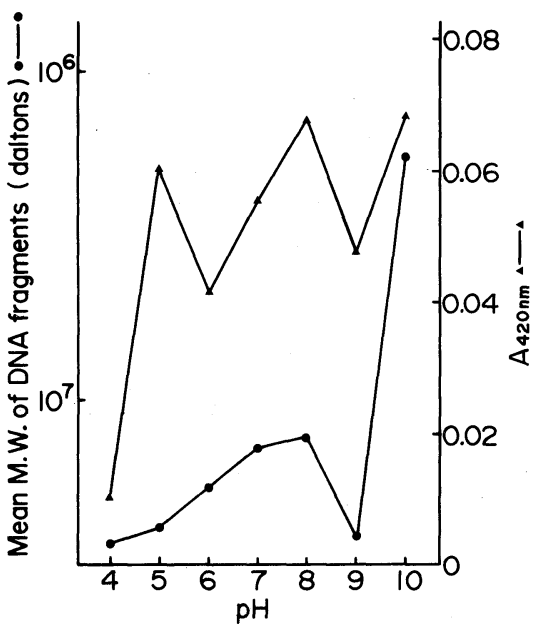

FIG. 8. Effects of $\mathrm{pH}$ on the DNA-Breaking Activity and the Oxidation of Hexagalloyl Glucose.

$\lambda$ DNAs were treated with the mixture of $25 \mu \mathrm{M}$ HGG and $200 \mu \mathrm{M} \mathrm{Cu}^{2+}$ in $50 \mathrm{~mm}$ buffers having various $\mathrm{pH}$ values at $37^{\circ} \mathrm{C}$ for $2 \mathrm{hr}$ and the decrease of the mean molecular weights of DNA fragments was investigated. Oxidation of HGG was followed by measuring the increase of absorbance at $420 \mathrm{~nm}$ after the incubation of the mixture of $60 \mu \mathrm{M}$ HGG, $200 \mu \mathrm{M} \mathrm{Cu}{ }^{2+}$ and $8 \mathrm{~mm}$ buffers. We used acetate buffer for $\mathrm{pH} 4$ and 5, phosphate buffer for $\mathrm{pH} 6$, 7, and 8, Tris- $\mathrm{HCl}$ buffer for $\mathrm{pH} 9$ and carbonatebicarbonate buffer for $\mathrm{pH} 10$.

ation of $\mathrm{HGG}$ was accelerated in alkaline conditions, the enhancement of the breaking activity of HGG with increasing $\mathrm{pH}$ was supposed to be correlated with the increasing rate of the $\mathrm{Cu}^{2+}$-catalyzed oxidation of tannins. The zigzag relation between the breaking activity or oxidation rate of tannin and $\mathrm{pH}$ was assumed to be related to differences in the buffers used, because the breakage or oxidation rate of $\mathrm{HGG}$ increased at higher $\mathrm{pH}$ in the same sort of buffer. Since the buffer can interact with metallic ions as well as protons, it may influence the breakage by tannins in the presence of metallic ions.

\section{DISCUSSION}

DNA breakage, especially double-stranded DNA breakage, is assumed to influence many functions of cells. Although single-strand breaks caused by epinephrine, an aromatic reductone, are rapidly repaired, double-strand breaks are retained for a long time, resulting in changes of cell functions. ${ }^{25}$ ) There is a hypothesis that appropriate breakages of DNA can initiate carcinogenesis, carcinostasis, cytodifferenciation, mutation, or virogenesis. ${ }^{26)}$ We found double-strand breaks caused by pure hydrolyzable tannins. The activity changed variously according to the sorts, numbers, and binding positions of the constituent acids and polyalcohols.

A prominent feature of the DNA breakage by hydrolyzable tannins was the suppression of the activity at concentrations higher than $100 \mu \mathrm{M}$ of tannins. Since the suppression was released by the increase of $\mathrm{Cu}^{2+}$ concentration, a deficiency of $\mathrm{Cu}^{2+}$ which could participate the breaking reaction was supposed to be the cause of the suppression. Tannins are known to be potent chelators of metallic ions, and form insoluble precipitates with $\mathrm{Cu}^{2+}{ }^{27)}$ When $\mathrm{Cu}^{2+}$ is chelated by higher concentrations of tannins in such a form that $\mathrm{Cu}^{2+}$ can no longer be used in the breaking reaction, the breaking reaction might be suppressed.

Because no breakage was observed by $\mathrm{Cu}^{2+}$ alone, it was obvious that both tannins and $\mathrm{Cu}^{2+}$ were indispensable for the DNAbreaking reaction. The complex behavior of hydrolyzable tannins in the breaking reaction compared with that of gallic acid may be associated with the complex structures of tannins carring many binding sites for $\mathrm{Cu}^{2+}$. HGG exhibited a maximum activity at the $\mathrm{Cu}^{2+}$ concentration of $0.5 \mathrm{~mm}$. The activity was weakened at higher concentrations of $\mathrm{Cu}^{2+}$ than $0.5 \mathrm{~mm}$. Such a tendency is known in the case of ascorbic acid. ${ }^{28,29)}$ This suggested that $\mathrm{Cu}^{2+}$ didn't work only as the catalyzer of the oxidation of tannins. Because $\mathrm{Cu}^{2+}$ can bind to DNA, ${ }^{30,31)}$ the interaction of DNA, $\mathrm{Cu}^{2+}$ and tannins may be important in the breaking reaction.

In the metal-catalyzed oxidation process of tannins, such secondary radical products as $\cdot \mathrm{OH}, \cdot \mathrm{O}_{2}^{-}$, and $\mathrm{H}_{2} \mathrm{O}_{2}$ are supposed to be produced concomitantly and are assumed to take part in the DNA breaking reaction. The fact that DMSO, which is known as a scavenger for 
- OH radicals, strongly inhibited DNA breakage by HGG suggested the participation of - $\mathrm{OH}$ radicals in the breaking reaction. However, since the oxidation process of hydrolyzable tannins is very complex, the identification of the intermediate responsible for the DNA breakage is not easy. The detailed mechanism of the DNA-breaking reaction by hydrolyzable tannins is under investigation.

Acknowledgment. This work was supported in part by a Grant-in-Aid for Scientific Research from the Ministry of Education, Science and Culture of Japan.

\section{REFERENCES}

1) I. Nishioka, Yakugaku Zasshi, 103, 125 (1983).

2) K. Yamafuji and H. Murakami, Enzymologia, 35, 139 (1968).

3) K. Yamafuji, H. Murakami and M. Shinozuka, Z. Krebsforsch., 73, 195 (1970).

4) K. Yamafuji, Y. Nakamura, H. Omura, T. Soeda and K. Gyotoku, Z. Krebsforsch., 76, 1 (1971).

5) S. Shirahata, H. Murakami, K. Yamada and H. Omura, Nippon Nôgeikagaku Kaishi, 56, 1027 (1982).

6) H. Murakami, S. Shirahata, C. Hori, H. Yoshii, K. Yamada, K. Shinohara and H. Omura, Agric. Biol. Chem., 43, 1619 (1979).

7) M. V. Norgard, K. Emigholz and J. J. Monahan, J. Bacteriol., 138, 270 (1979).

8) A. Colman, M. J. Byers, S. B. Brimrose and A. Lyons, Eur. J. Biochem., 91, 303 (1978).

9) G. Nonaka and I. Nishioka, Chem. Pharm. Bull., 31, 1652 (1983).

10) G. Nonaka and I. Nishioka, Chem. Pharm. Bull., 29, 2862 (1981).

11) unpublished data.

12) M. Nishizawa, T. Yamagishi, G. Nonaka and I. Nishioka, J. Chem. Soc., Perkin Trans. 1, 961 (1983).
13) M. Nishizawa, T. Yamagishi, G. Nonaka and I. Nishioka, J. Chem. Soc., Perkin Trans. 1, 2963 (1982).

14) G. Nonaka, K. Ishimaru, T. Tanaka and I. Nishioka, Chem. Pharm. Bull., 32, 483 (1984).

15) H. Nishimura, G. Nonaka and I. Nishioka, Chem. Pharm. Bull., 32, 1741 (1984).

16) G. Nonaka, M. Harada and I. Nishioka, Chem. Pharm. Bull., 28, 685 (1980).

17) G. Nonaka, T. Tanaka and I. Nishioka, J. Chem. Soc., Perkin Trans. 1, 1067 (1982).

18) G. Nonaka, T. Tanaka and I. Nishioka, J. Chem. Nishizawa and T. Yamagishi, Chem. Pharm. Bull., 29, 1184 (1981).

19) S.-H. Shiou, J. Biochem., 94, 1259 (1983).

20) D. E. Pulleyblank, M. Shure and J. Vinograd, Nucleic Acids Res., 4, 1409 (1977).

21) A. Prunell, F. Strauss and B. Leblanc, Anal. Biochem., 78, 57 (1977).

22) K. Murray and N. E. Murray, J. Mol. Biol., 98, 551 (1975).

23) R. J. Roberts, Nucleic Acids Res., 10, 117 (1982).

24) C. P. Ordahl, T. R. Johnson and A. I. Caplan, Nucleic Acids Res., 3, 2985 (1976).

25) H. Murakami, T. Miyoshi, M. Koga, K. Yamada and H. Omura, Agric. Biol. Chem., 39, 795 (1975).

26) K. Yamafuji, "Food, Cancer and Cytodifferentiation," Shukosha, Fukuoka, Japan, 1970.

27) T. Okuda, K. Mori, M. Shiota and K. Ida, Yakugaku Zasshi, 102, 35 (1982).

28) K. Shinohara, M. So, M. Nonaka, K. Nishiyama, H. Murakami and H. Omura, J. Nutr. Sci. Vitaminol., 29, 491 (1983).

29) K. Shinohara, M. So, M. Nonaka, K. Nishiyama, H. Murakami and H. Omura, J. Nutr. Sci. Vitaminol., 29, 489 (1983).

30) Ch. Zimmer, G. Luck, H. Fritzsche and H. Triebel, Biopolymers, 10, 441 (1971).

31) H. Richard, J. P. Schreiber and M. Daune, Biopolymers, 12, 1 (1973). 